\title{
AUSTRIJSKA KNJIŽNICA \\ NA FILOZOFSKOM FAKULTETU U ZAGREBU
}

\author{
AUSTRIAN LIBRARY AT THE FACULTY \\ OF HUMANITIES AND SOCIAL SCIENCES IN ZAGREB
}

\author{
Blaženka Klemar Bubić \\ Filozofski fakultet Zagreb \\ bklemar@ffzg.hr \\ Dubravka Luić-Vudrag \\ Filozofski fakultet Zagreb \\ dlvudrag@ffzg.hr
}

\author{
UDK / UDC 027.2(436):027.7(497.5) \\ Stručni rad / Professional paper \\ Prihvaćeno / Accepted: 27. 4. 2017.
}

\section{Sažetak}

Knjižnica Filozofskog fakulteta u Zagrebu (u daljnjem tekstu: Knjižnica FF) otvorila je u lipnju 2015., na inicijativu Austrijskog veleposlanstva, Austrijskog kulturnog foruma Zagreb i Odsjeka za germanistiku, Austrijsku knjižnicu Zagreb (u daljnjem tekstu: AKZ). Građa ima status trajne posudbe jer nije u vlasništvu Knjižnice Filozofskog fakulteta, ali se koristi prema njezinu pravilniku. Prva Austrijska knjižnica otvorena je 1986. u Krakovu. Na inicijativu tadašnjeg ministra vanjskih poslova dr. Aloisa Mocka počele su se sustavno otvarati, ponajprije na području bivše Habsburške Monarhije. Knjižnice olakšavaju pristup literaturi, znanosti i informacijama iz Austrije, daju velik doprinos širenju njemačkog jezika i austrijske kulture te služe poticanju i produbljivanju kulturne i znanstvene suradnje. Nova zbirka obogatila je Knjižnicu Filozofskog fakulteta u Zagrebu i donijela brojne obveze te dodatne mogućnosti suradnje s austrijskim kulturnim i znanstvenim institucijama.

Ključne riječi: Knjižnica Filozofskog fakulteta u Zagrebu, Austrijska knjižnica Zagreb, Knjižnice između osnivača i korisnika, darovi

Vjesnik bibliotekara Hrvatske 60, 1(2017), 205-220

ISSN 0507-1925

(C) VBH 2017. 


\section{Summary}

The Library of the Faculty of Humanities and Social Sciences Zagreb opened the Austrian Library Zagreb in July 2015 at the initiative of the Embassy of Austria in Zagreb, the Austrian Cultural Forum Zagreb, and the Department of German, Faculty of Humanities and Social Sciences, University of Zagreb. By the agreement the Austrian library materials are not the property of the Faculty Library, but are given to be used as a permanent loan. However, the Austrian library materials are being used according to the circulation policy of the Faculty Library.

The first Austrian Library abroad was opened in 1986 in Krakow, Poland. Many of the Austrian Libraries abroad were opened at the initiative of the former Austrian Minister of Foreign Affairs, Dr. Alois Mock, primarily in the countries of the former Habsburg Monarchy. These libraries enable access to the Austrian literature, science, and general information on Austria, but they also contribute greatly to the spreading of the German language and Austrian culture. More than that, they are an important incentive for deepening of cultural and scientific collaboration. This new library collection presents a significant enrichment for the Library of the Faculty of Humanities and Social Sciences in Zagreb. The Austrian library has brought many responsibilities and obligations, but has also opened many additional possibilities for collaboration with Austrian cultural and scientific institutions.

Keywords: Library of the Faculty of Humanities and Social Sciences Zagreb, Austrian Library Zagreb, libraries between founders and users, donations

\section{Uvod}

U radu se nastoji prikazati Austrijska knjižnica Zagreb, njezina povijest, nastanak i razvoj, te ju se pokušava staviti u širi društveni kontekst. Iako bi se po mnogim činjenicama poput naziva knjižnice, zemljopisnom smještaju, činjenici da se austrijski kulturni instituti i austrijske knjižnice u inozemstvu ponajprije osnivaju na mjestima gdje ima najviše pripadnika austrijske manjine, zatim po povijesti Republike Hrvatske, tj. grada Zagreba koji je dugi niz godina bio pod Habsburškom Monarhijom, Austrijskim Carstvom, odnosno Austro-Ugarskom, po kulturnom nasljeđu i identitetu grada Zagreba koji je ponajprije vidljiv u lokalnom zagrebačkom govoru, kako stoji u predgovoru Agramera, rječnika njemačkih posuđenica u zagrebačkom govoru, ,Zagreb je oduvijek bio mjesto dodira kultura i jezika“. ${ }^{1}$ „Osobito je jaka bila veza Zagreba i Austrije, i to ne samo politički; u srednjoeuropskom se okruženju jednako tako radilo i o kulturnim dodirima“" ${ }^{\text {" }}$ te

\footnotetext{
1 Agramer, rječnik njemačkih posuđenica u zagrebačkom govoru / Zrinjka Glovacki-Bernardi, Lara Hölbing Matković, Sanja Petrušić-Goldstein. Zagreb : Novi Liber, 2013. Str. 6.

2 Isto.
} 
broju pripadnika austrijske i njemačke nacionalne manjine u gradu Zagrebu. Prema popisu stanovništva iz 2011. godine (104 Austrijanaca i 364 Nijemaca) ${ }^{3}$ moglo bi se zaključiti da se radi o knjižnici za multikulturne zajednice, tj. o manjinskoj knjižnici Austrijanaca i Nijemaca poput Austrijske čitaonice u Osijeku - Središnje knjižnice Nijemaca i Austrijanaca. ${ }^{4}$

Ulazeći dublje u analizu korisnika knjižnice i čitaonice Austrijskog kulturnog instituta, kasnije Austrijskog kulturnog foruma u Zagrebu, vidljiva je potreba za promjenom. Tako knjižničarka u Austrijskom kulturnom forumu navodi sljedeće: „Pripadnici austrijske i njemačke nacionalne manjine bili su najbrojniji u 60-im, 70-im i 80-im godinama, a od 90-ih do 2005. taj broj vidljivo je opadao. U posljednjih deset godina djelovanja knjižnice i čitaonice u Gundulićevoj ulici, od 2005. do 2015., jedva da je bila posjećivana od strane pripadnika tih dviju manjina. Glavni razlog tomu jest to što je generacija austrijske i njemačke manjine koja se aktivno služila njemačkim jezikom umrla ili ostarjela te polako odumire." ${ }^{\text {"5 }}$

Prve inicijative za osnivanjem Austrijske knjižnice Zagreb pokrenute su već 2007. godine od strane tadašnjeg voditelja Austrijskog kulturnog foruma Christiana Ebnera, pozivom predstavnika Odsjeka za germanistiku Filozofskog fakulteta u Zagrebu i voditeljice knjižnice Odsjeka za germanistiku na Susret njemačkih knjižnica u Hrvatskoj (30. studenoga - 1. prosinca 2007.), ali nisu urodile plodom sve do lipnja 2015. godine.

Austrijska je knjižnica Zagreb visokoškolska, tj. fakultetska knjižnica, koja se svojim sadržajem, uslugama i programom u potpunosti okrenula studentima i znanstveno-nastavnom osoblju. „Visokoškolske knjižnice su institucije koje prikupljaju, obrađuju, pohranjuju i daju na korištenje dokumente i informacije znanstvenog, obrazovnog i općekulturnog karaktera. Visokoškolske su knjižnice sastavni dio znanstveno-nastavne i istraživačke infrastrukture" ${ }^{\text {" }}$ i njihova izgradnja zahtijeva ,praćenje potreba i zahtjeva korisnika““7 $\mathrm{i}$,unapređenje znanstvenih i nastavnih potreba matičnog odjela“8 .

Dodatna potvrda ispravnog postupanja u prenamjeni knjižnice jest to što od 2015. godine, kada je otvorena Austrijska knjižnica Zagreb, nismo imali nijednog korisnika koji je pripadnik austrijske ili njemačke nacionalne manjine.

\footnotetext{
3 Popis stanovništva, kućanstva i stanova 2011. Stanovništvo prema narodnosti po gradovima/ općinama. Dostupno na http://www.dzs.hr/Hrv/censuses/census2011/results/htm/H01_01_04/ h01_01_04_RH.html [citirano: 2017-20-4].

4 Todorčev Hlača, Katarina. Strategija razvoja središnjih knjižnica nacionalnih manjina unutar mreže narodnih knjižnica. // Vjesnik bibliotekara Hrvatske 58,1-2(2015), str. 49.

5 Karlović, Zvjezdana. Korisnici Austrijske knjižnice. Privatna poruka (19.4.2017.)

6 Standardi za visokoškolske knjižnice u Republici Hrvatskoj. // Vjesnik bibliotekara Hrvatske 33 1-4(1990), str. 201.

7 Isto.

8 Isto.
} 


\section{Austrijske knjižnice u svijetu}

Prva austrijska knjižnica otvara se 1986. u Krakovu u Poljskoj. Tadašnji ministar vanjskih poslova Republike Austrije dr. Alois Mock, nakon političkih promjena u Europi, od 1989. godine sustavno pokreće program za lektore njemačkog jezika kako bi širili jezik te ponovno ojačali kulturne veze s Austrijom. U svrhu podrške tom programu u gradovima u kojima se nalaze sveučilišta, a nema Austrijskih kulturnih foruma, otvara austrijske knjižnice. ${ }^{9}$

U posljednjih trideset godina, tj. od 1986. godine, osnovano je 65 austrijskih knjižnica u 28 država svijeta. Prema izvješću ${ }^{10}$ za 2015. godinu cjelokupan fond austrijskih knjižnica iznosi 432000 jedinica knjižnične građe. Austrijske knjižnice godišnje imaju oko 388000 korisnika i zajedno organiziraju oko tisuću različitih kulturnih i znanstvenih događanja poput konferencija, radionica, predstavljanja knjiga, natječaja, izložbi, filmskih večeri i sl.

Najveći broj nalazi ih se na području bivše Habsburške Monarhije. S vremenom se knjižnice šire i izvan tog područja, čak i izvan same Europe - u središnju Aziju i na Bliski istok. Knjižnice se prostiru na području od Sankt-Peterburga (Ruska Federacija) na sjeveru i Jeruzalema (Izrael) na jugu do Trenta (Italija) na zapadu i Biškeka (Kirgistan) na istoku (slika 1).

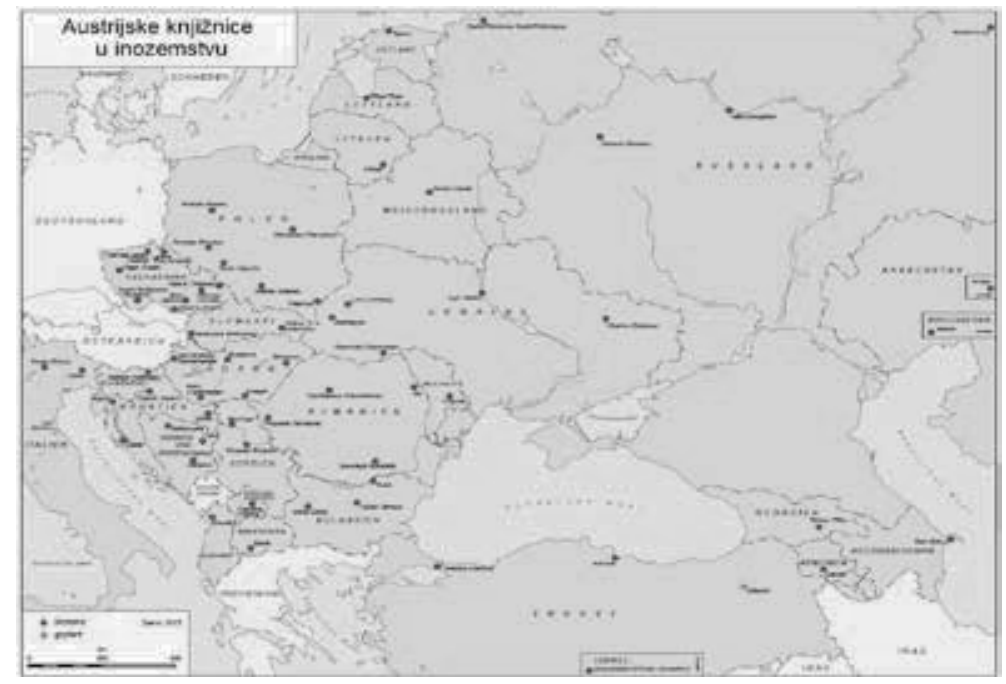

Slika 1. Karta austrijskih knjižnica u inozemstvu ${ }^{11}$

\footnotetext{
9 Usp. Über uns : Geschichte // Österreich-Bibliotheken im Ausland. [citirano: 2017-19-1]. Dostupno na http://www.oesterreich-bibliotheken.at/.

10 Isto.

11 Die Bibliotheken : Landkarte // Österreich-Bibliotheken im Ausland. [citirano: 2017-20-1]. Dostupno na http://www.oesterreich-bibliotheken.at/landkarte.pdf.
} 
Brojkama iskazano, najviše austrijskih knjižnica nalazi se u Češkoj, i to sveukupno devet, šest u Poljskoj, po pet u Mađarskoj i Ukrajini, po četiri u Ruskoj Federaciji i Hrvatskoj, po tri u Bosni i Hercegovini, Bugarskoj i Rumunjskoj, po dvije u Sloveniji, Italiji, Srbiji i Turskoj, a u ostalim državama (Albaniji, Armeniji, Azerbajdžanu, Bjelorusiji, Estoniji, Gruziji, Izraelu, Kazahstanu, Kirgistanu, Kosovu, Latviji, Litvi, Makedoniji, Moldaviji i Sloveniji) po jedna (slika 2).

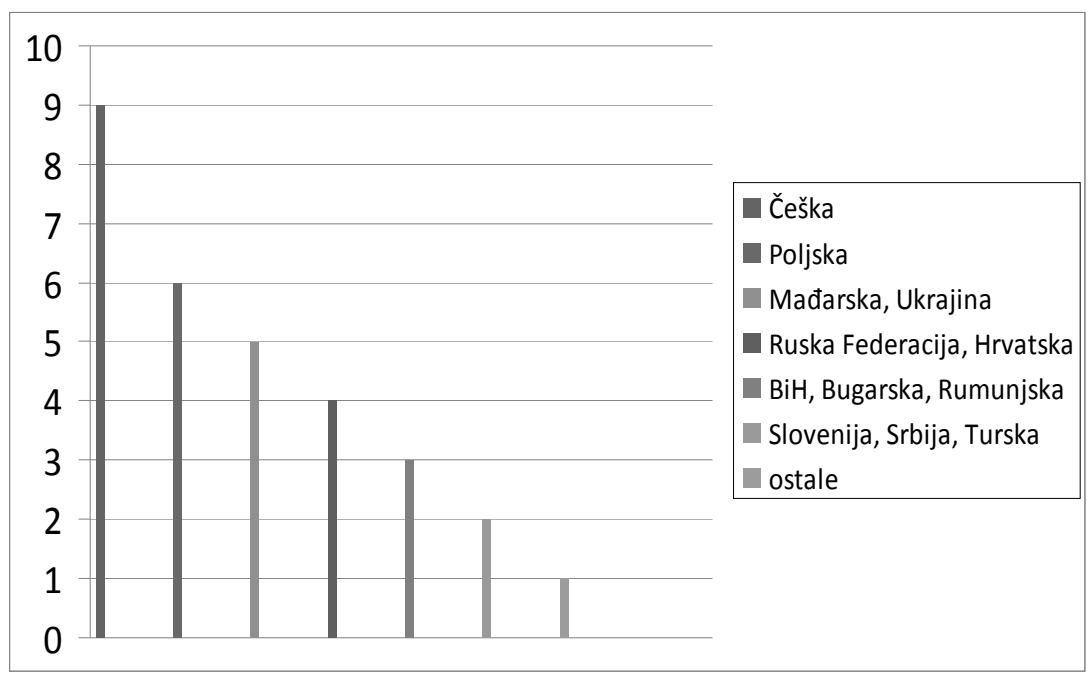

Slika 2. Brojčani prikaz knjižnica po državama ${ }^{12}$

Ciljevi austrijskih knjižnica su fleksibilno i inovativno oblikovanje kulturne politike, pristup austrijskoj književnosti, znanosti, kulturi i informacijama iz Austrije. Knjižnice su javno dostupne i ne naplaćuju članarinu. Najčešći su im korisnici nastavno i znanstveno osoblje, učenici, studenti i pripadnici njemačke nacionalne manjine. Odjel za kulturu Saveznoga ministarstva za Europu, integraciju i međunarodne poslove Republike Austrije uz potporu lokalnih veleposlanstava i austrijskih kulturnih foruma vodi organizaciju i koordinaciju austrijskih knjižnica u svijetu te financira nabavu, a infrastrukturu i osoblje osiguravaju ustanove $u$ kojima su smještene knjižnice. O svakoj knjižnici brine znanstveni voditelj, najčešće sveučilišni profesor, germanist, koji se bavi temama vezanim uz austrijsku književnost ili jezik, knjižničar i austrijski lektor.

Na mrežnoj stranici Österreich-Bibliotheken im Ausland (http://www.oesterreich-bibliotheken.at/) nalazi se svojevrsna platforma koja služi umrežavanju austrijskih knjižnica u inozemstvu, pohranjuje narudžbe, račune, izvještaje, najave i arhivu događanja. Na njoj su svi podaci o povijesti i ciljevima projekta austrijskih

12 Usp. Die Bibliotheken : Bibliotheksverzeichnis // Österreich-Bibliotheken im Ausland. [citirano: 2017-21-1]. Dostupno na http://www.oesterreich-bibliotheken.at/verzeichnis.php. 
knjižnica u inozemstvu. S te mrežne stranice može se preko popisa knjižnica pristupiti podacima o svakoj pojedinoj knjižnici, kratkoj povijesti njezina nastanka, opisu fonda, podacima za kontakt, katalogu svake pojedine knjižnice, mrežnim i Facebook-stranicama. Cilj je u budućnosti napraviti veliku virtualnu knjižnicu.

Matične ustanove pri kojima se nalaze austrijske knjižnice najčešće su nacionalne i/ili sveučilišne knjižnice, a rjeđe, poput Austrijske knjižnice Zagreb, fakultetske, narodne, knjižnice raznih društava, udruženja i centara ili knjižnice akademija znanosti. Detaljnim pregledom austrijskih knjižnica dobiveni su rezultati prikazani na slici 3 .

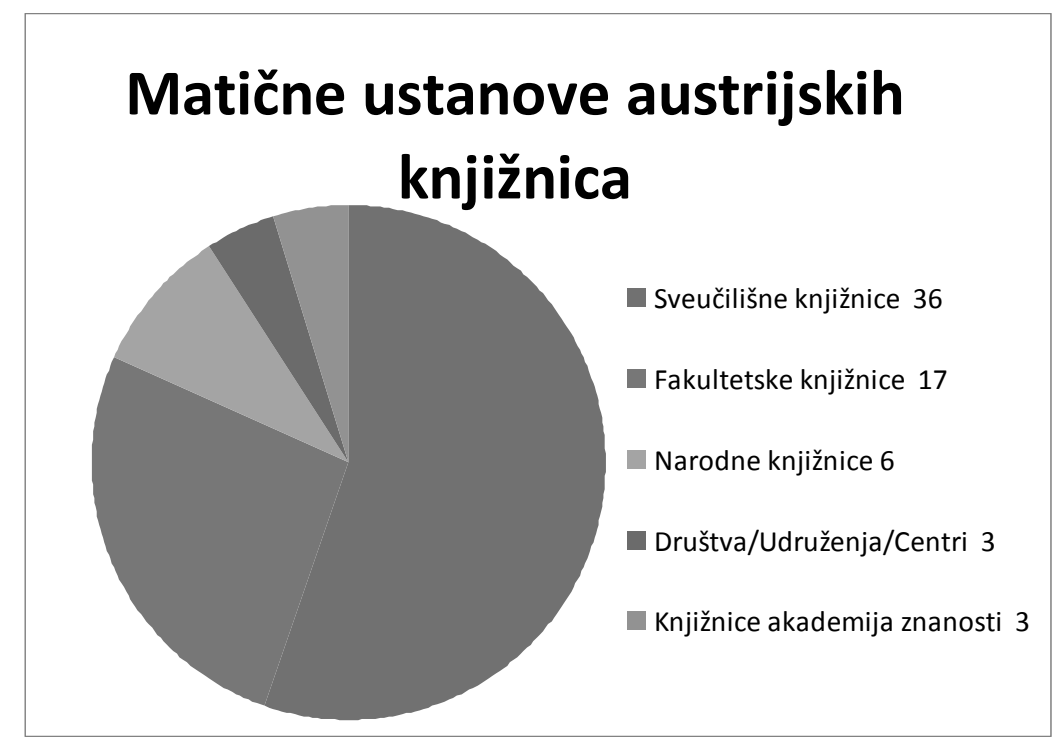

Slika 3. Matične ustanove austrijskih knjižnica ${ }^{13}$

\section{Austrijske knjižnice u Hrvatskoj}

Otvaranje Austrijskih knjižnica u Hrvatskoj izraz je bliskih odnosa Austrije i Hrvatske. Austrijske knjižnice obično se opremaju osnovnim fondom od oko 3500 svezaka reprezentativnih djela i periodičkih publikacija, a daljnji razvoj knjižnica ovisi o specifičnosti sredine u kojoj se knjižnice nalaze. ${ }^{14}$ Sva građa, kako osnovni

13 Isto.

14 Usp. Stanarević, Snježana; Siniša Petković; Darko Lacović. Petnaest godina djelovanja Austrijske čitaonice pri Gradskoj i sveučilišnoj knjižnici Osijek. // 6. međunarodni stručni skup Knjižnica - središte znanja i zabave : zbornik radova. Karlovac: Gradska knjižnica „Ivan Goran Kovačić“", 2008. Str. 35. 
fond tako i daljnja nabava, pristiže u obliku dara Ministarstva Republike Austrije. Građa austrijske knjižnice ne ulazi u fond matične knjižnice pri kojoj se nalazi, već se za nju vodi posebna inventarna knjiga.

U Hrvatskoj tako djeluju četiri austrijske knjižnice. Prva austrijska knjižnica, odnosno austrijska čitaonica u Hrvatskoj otvara se u Osijeku 19. listopada 1995. godine (Österreich-Bibliothek Osijek) kao zaseban odjel pri Gradskoj i sveučilišnoj knjižnici u Osijeku. S obzirom na to da prema popisu stanovništva provedenom 2001. godine trećina svih Nijemaca u Republici Hrvatskoj živi u Osječko-baranjskoj županiji ${ }^{15}$, a i zbog, kako kaže autorica Marija Erl Šafar, „same povijesne i kulturne povezanosti slavonskog prostora s Austrijom, od 1687. do 1918. godine ${ }^{\text {"16 }}$, razumljivo je da se prva austrijska knjižnica, koja je ujedno i središnja knjižnica Nijemaca i Austrijanaca u Republici Hrvatskoj ${ }^{17}$, otvara upravo u Osijeku, koji Vlado Obad naziva „,najstarijim njemačkim gradom na jugoistoku“. ${ }^{18}$ Na području Osječko-baranjske županije djeluje šest udruga koje brinu o kulturnom životu austrijske i njemačke nacionalne manjine, pa tako Hrvatsko-austrijsko društvo djeluje upravo u Austrijskoj čitaonici Osijek. ${ }^{19}$ Fond Austrijske čitaonice ima oko 8000 naslova, a formiran je sukladno djelatnosti matične ustanove u kojoj se nalazi, tj. narodnoj i sveučilišnoj djelatnosti. Poput svake narodne knjižnice, zastupljeni su svi žanrovi za sve dobne skupine s osobitim naglaskom na književnosti i povijesti te referentnoj zbirci rječnika, leksikona, gramatika i enciklopedija, koja naglašava njezinu ulogu sveučilišne, ali i multikulturne knjižnice. ${ }^{20} \mathrm{U}$ knjižnici ili u suradnji s knjižnicom, a uz potporu Austrijskog kulturnog foruma u Zagrebu i lokalnih kulturnih institucija, poput Hrvatskog narodnog kazališta, Arheološkog muzeja, Galerije likovnih umjetnosti, Osječkih kinematografa, Katedre za germanistiku Filozofskog fakulteta Sveučilišta u Osijeku, osnovnih i srednjih škola te vrtića u kojima se uči njemački jezik, organiziraju se književne i glazbene večeri, predavanja, izložbe, prikazivanja filmova, promocije, učenički i studentski posjeti, radionice, obilježavanja određenih dana u godini itd. Korisnici su ponajprije pripadnici austrijske i njemačke nacionalne manjine, studenti i nastavnici Filozofskog fakulteta u Osijeku, ponajprije studenti germanistike, umirovljenici, školarci i predškolci koji uče njemački jezik. ${ }^{21}$

\footnotetext{
15 Isto, str. 34.

16 Erl Šafar, Marija. Knjižnica u multikulturalnoj sredini-Austrijska čitaonica Gradske i sveučilišne knjižnice Osijek. // 4. međunarodni stručni skup Knjižnica - središte znanja i zabave : zbornik radova. Karlovac: Gradska knjižnica „Ivan Goran Kovačić“, 2008. Str. 98.

17 Todorčev Hlača, Katarina. Nav. dj., str. 49.

18 Usp. Obad, Vlado. Roda Roda und die deutschsprachige Literatur aus Slawonien. Wien; Köln; Weimar: Böhlau, 1996. Str. 9.

19 Usp. Stanarević, Snježana; Siniša Petković; Darko Lacović. Nav. dj., str. 35.

20 Isto., str. 37.

21 Isto.
} 
Druga austrijska knjižnica u Hrvatskoj otvara se 23. rujna 2011. godine pri Filozofskom fakultetu Sveučilišta u Rijeci (Österreich-Bibliothek Rijeka). Knjižnica je smještena na Filozofskom fakultetu, točnije na Odsjeku za germanistiku. Knjižnica ima ukupni fond od oko 4000 naslova, prije svega iz područja književnosti, lingvistike, povijesti, psihologije i sociologije te manju zbirku recentnih časopisa. Knjižnica je visokoškolska, tj. fakultetska te olakšava pristup literaturi i informacijama iz Austrije, a u suradnji s Austrijskim kulturnim forumom u Zagrebu organizira niz kulturnih događanja, poput književnih i filmskih večeri i izložbi, koja su često dvojezična kako bi privukla veći broj posjetitelja, a u suradnji sa sveučilištima iz Republike Austrije organizira i stručne i znanstvene radionice te predavanja namijenjene prije svega znanstvenom i nastavnom osoblju i studentima germanistike. S ciljem promicanja njemačkog jezika pokrenuti su i razni projekti na kojima volontiraju studenti Odsjeka za germanistiku. ${ }^{22}$

Treća po redu, Austrijska knjižnica „Dr. Alois Mock“ (Österreich-Bibliothek Zadar) otvorena je 1. srpnja 2013. godine pri Sveučilišnoj knjižnici u Zadru. Knjižnica ima ukupni fond od oko 2500 naslova i manji broj recentnih časopisa kao što su Manuskripte, Österreich-Spiegel i dr. te digitalne medije. Težište je fonda prije svega u području austrijske književnosti, zatim teorije književnosti, jezikoslovlja, a slijede knjige iz filozofije, povijesti, kao i one o austrijskoj politici, arhitekturi, umjetnosti, metodici nastave njemačkog jezika, povijesti, umjetnosti i glazbi te manji dio knjiga dječje književnosti. Knjižnica je visokoškolska, tj. fakultetska, građa je javno dostupna svima, ali je posudba dopuštena samo studentima i zaposlenicima Sveučilišta u Zadru. U suradnji s Odsjekom za germanistiku i Austrijskim kulturnim forumom u Zagrebu organizira književne i filmske večeri, radionice, predavanja, izložbe i glazbene večeri ponajprije za studente, ali i za učenike njemačkog jezika. ${ }^{23}$

\section{Povijest Austrijske knjižnice Zagreb}

Austrijska čitaonica (Österreichische Lesehalle) u Zagrebu osnovana je 1955. godine, prije nešto više od 60 godina. Nakon Drugog svjetskog rata i ponovne neovisnosti Austrije, Savezno ministarstvo za prosvjetu počinje s osnivanjem kulturnih instituta u zapadnim zemljama i na području bivše Habsburške Monarhije. U Gundulićevoj 3 1955. godine počinje djelovati Austrijska čitaonica. U Socijalističkoj Federativnoj Republici Jugoslaviji njemački nije bio popularan. S obzirom na višestoljetne povijesne, kulturne i gospodarske veze Hrvatske i Austrije i s obzirom na potrebu za svim segmentima austrijske kulture, od kojih je nakon 1945. godine Hrvatska bila u potpunosti odijeljena, a zahvaljujući zagrebačkom građanstvu koje se tada još uvijek u velikom broju dobro služilo njemačkim jezikom,

22 Stojić, Aneta. Austrijska knjižnica Rijeka. Privatna poruka. (6.4.2017.)

23 Pavić Pintarić, Anita. Austrijska knjižnica Zadar. Privatna poruka. (13.4.2017.) 
nailazi na velik broj zainteresiranih korisnika, pa tako vrlo brzo prerasta u veliku posudbenu knjižnicu s gotovo 7000 knjiga, prije svega austrijske književnosti, 300 nota i 400 ploča. Čitaonica u svom prostoru utorkom navečer održava predavanja, književne i filmske večeri, izložbe, koncerte i dr., pa su po tome događanja i dobila ime „Večer utorkom“, a prva takva večer održana je 13. prosinca 1955.

Prema godišnjem izvješću ${ }^{24}$ za 1957./58. vidimo da Čitaonica ima 1500 članova i da u nju dnevno dolazi oko 60 korisnika, 1961. godine ima 2347 korisnika, a 1962. više od 2500 članova. Godina 1961. važna je za Čitaonicu jer ona tada dobiva Statut "koji joj je omogućio djelatnost analognu onoj kakvu je u Jugoslaviji obavljao British Council ili Institut Français““. ${ }^{25}$ Iako od samog osnutka Čitaonica ima ulogu kulturnog instituta, tek 1976. dobiva naziv Austrijski kulturni institut (Österreichisches Kulturinstitut).

O visokim kriterijima kojima se predstavljala austrijska kultura svjedoče pisma čiji pošiljatelji spadaju u najpoznatije suvremene austrijske književnike: Heimito von Doderer, Elias Canetti (kasniji nobelovac), Peter Turrini, Peter Handke i mnogi drugi. Osim događanja u svom prostoru, Čitaonica organizira kazališne predstave, koncerte, izložbe i simpozije i u drugim institucijama grada Zagreba. Godine 2001. Austrijski kulturni institut mijenja ime u Austrijski kulturni forum (Österreichisches Kulturforum), a 2005. ima 3000 upisanih korisnika ${ }^{26} \mathrm{Knjižnicu}$ je 1999. godine zadesila velika poplava u kojoj je uništeno oko 500 knjiga, no usprkos tomu ona je 2015. imala fond od 15600 knjiga i 4600 upisanih korisnika. Kako više nije u trendu posjećivati malu čitaonicu u centru grada, aktivnih je korisnika bilo sve manje. Unazad 5-6 godina (2010.-2015.) ta je brojka pala na svega stotinjak aktivnih korisnika ${ }^{27}$, pa je tako odlučeno da se Knjižnica približi široj publici i drugačijem profilu korisnika.

Osnivanje Knjižnice bilo je izuzetno složen zadatak zbog uključenosti raznih institucija, poput Saveznog ministarstva za Europu, integraciju i međunarodne poslove Republike Austrije, Austrijskog veleposlanstva, Filozofskog fakulteta, Knjižnice Filozofskog fakulteta, Odsjeka za germanistiku (i ostalih Odsjeka FFZG-a koji su poduprli osnivanje AKZ-a, poput Odsjeka za povijest, Odsjeka za povijest umjetnosti i Odsjeka za komparativnu književnost), a time i povezanih pravnih okvira, tehničkih okolnosti i različitih interesa koje je trebalo uskladiti. ${ }^{28}$

\footnotetext{
24 Od utorka do utorka : Austrijski kulturni institut/forum u vlastitim dokumentima : spomen spis u povodu jubileja Austrijskog kulturnog foruma / priredila Truda Stamać. Zagreb : Durieux, 2006. Str. 12.

25 Isto., str. 17.

${ }^{26}$ Podaci pribavljeni ljubaznošću Zvjezdane Karlović, knjižničarke u Austrijskom kulturnom forumu Zagreb.

27 Isto.

28 Usp. Lacko Vidulić, Svjetlan. Tekst o Austrijskoj knjižnici Zagreb. Privatna poruka. (24. 4. 2017.)
} 
Povodom obilježavanja šezdesete godišnjice osnutka, Knjižnica Austrijskog kulturnog foruma 2015. prestaje sa svojim djelovanjem i postaje Austrijska knjižnica Zagreb.

Austrijska knjižnica Zagreb (Österreich-Bibliothek Zagreb) otvorena je 11. lipnja 2015. godine. Osnovu knjižnice čini 4500 svezaka preuzetih iz Knjižnice Austrijskog kulturnog foruma u Zagrebu, proširenih donacijom GRAWE osiguranja Hrvatska za nabavu vrijednih kritičkih izdanja, te je pribavljeno oko 470 primjeraka knjižne građe. Zbirku, osim referentnog dijela (velikog broja enciklopedija, leksikona, rječnika i gramatika), čini i zbirka primarne literature iz književnosti (18., 19. i 20. stoljeće, poslijeratna književnost i antologije), književni prijevodi, sekundarna literatura - kulturološke studije, znanost o književnosti, jezikoslovne studije, kultura i civilizacija, psihologija, filozofija, povijest, povijesne biografije, povijest umjetnosti, glazba, kazalište, film te 130 DVD-a s novijim i starijim filmovima iz Edicije Standard i 13 tekućih časopisa, a od listopada 2016. i tri vikend-izdanja dnevnog tiska: Die Presse, Der Standard i Wiener Zeitung. Knjižnica svoja događanja promovira na vlastitoj mrežnoj stranici Austrijska knjižnica Zagreb / Österreich-Bibliothek Zagreb (http://oesterreich-bibliothek-zagreb.jimdo.com/) i na Facebook-stranici Austrijska knjižnica Zagreb / Österreich-Bibliothek Zagreb (https://www.facebook.com/pages/Austrijska-knji\%C5\%BEnica-Zagreb-\%C3\%96sterreich-Bibliothek-Zagreb/375962885927501).

Uklapanje u Knjižnicu FF nije bilo nimalo jednostavno jer se radi o knjižnici čija je primarna uloga potpora znanstvenom radu na fakultetu te osiguravanje ispitne i seminarske literature. Prije potpisivanja sporazuma o osnivanju Austrijske knjižnice Zagreb između Saveznog ministarstva za Europu, integraciju i međunarodne poslove Republike Austrije i Sveučilišta u Zagrebu napravljena je, sukladno znanstvenoj i nastavnoj djelatnosti, selekcija građe fonda iz knjižnice Austrijskoga kulturnog foruma oko 15000 svezaka građe koja je dijelom bila zastarjela i samo dijelom zanimljiva knjižnici u koju se trebala uklopiti. U tom je dijelu Odsjek za germanistiku imao glavnu ulogu jer je mogao izravno utjecati na odabir građe, upravljanje knjižnicom i oblikovanje programa.

Kako smještaj građe AKZ-a nije mogao predstavljati iznimku od postojećih pravila, Filozofski fakultet osigurao je prostor u otvorenom pristupu, prostor $\mathrm{u}$ zatvorenom spremištu, ustupio prostorije i predvorje knjižnice za kulturne i znanstvene aktivnosti, osigurao integritet zbirke, smještaj, stručnu obradu, znanstvenog voditelja i knjižničara, po načinu korištenja izjednačio AKZ s ostalim zbirkama fakultetske knjižnice (više od 30 zbirki s fondom većim od 600000 jedinica građe, više od 9000 registriranih korisnika i preko 200000 transakcija građe) ${ }^{29}$ te osigurao korištenje građe za sve građane, a posudbu za studente i djelatnike fakulteta.

29 Isto. 
Savezno ministarstvo za Europu, integraciju i međunarodne poslove Republike Austrije (BMeiA) knjižnici Filozofskog fakulteta dalo je na posudbu nedjeljivu zbirku u vlasništvu Republike Austrije, osiguralo nabavu novih knjiga sukladno proračunskim mogućnostima te omogućilo boravak suradnika Austrijske knjižnice Zagreb u Republici Austriji u stručne i znanstvene svrhe u sveukupnom trajanju od četiri tjedna godišnje. Za pomoć pri izgradnji zbirke i organizaciji događanja osigurava pomoć austrijskog lektora te Austrijskog kulturnog foruma u Zagrebu. ${ }^{30}$

Austrijska knjižnica Zagreb u suradnji s Austrijskim kulturnim forumom organizira konferencije, gostujuća predavanja, radionice, predstavljanja knjiga, natječaje za studente, filmske večeri, izložbe i slično.

\subsection{Istraživanje o posudbi građe u Austrijskoj knjižnici Zagreb}

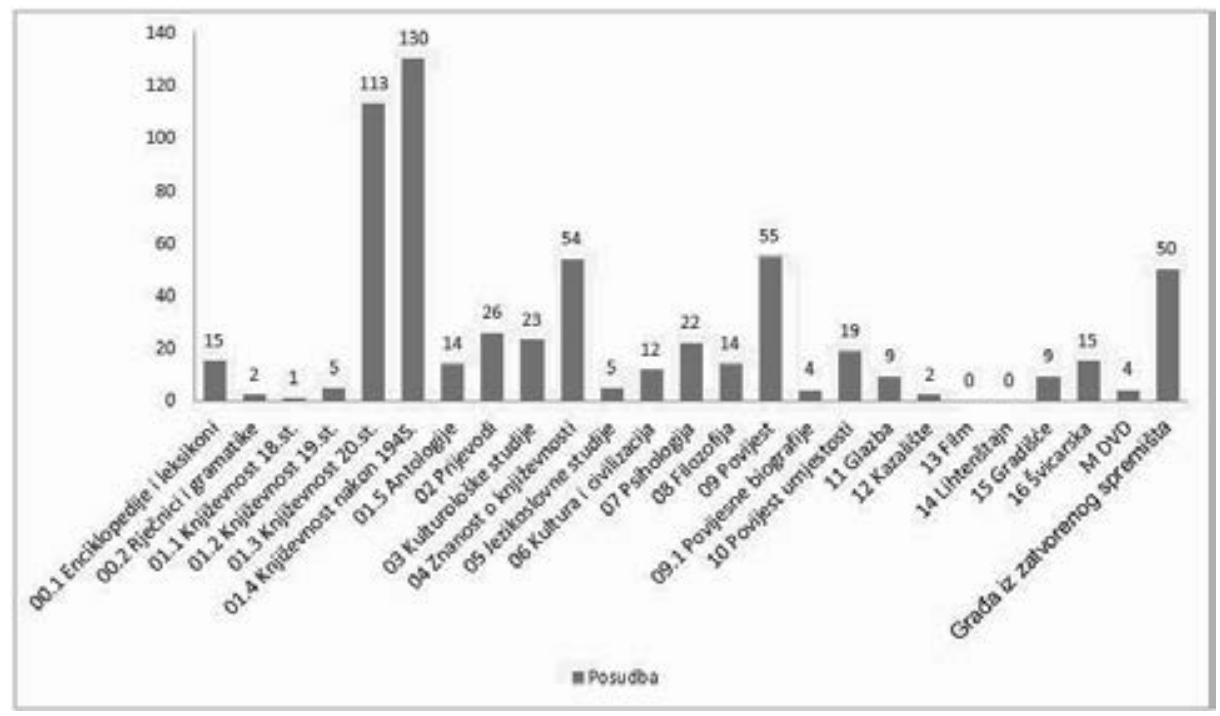

Slika 4. Rezultati istraživanja posudbe građe po stručnim skupinama

Zahvaljujući integriranom knjižničnom softveru KOHI za poslovanje u Knjižnici FF koji "obuhvaća kompletno knjižnično poslovanje, uključujući javni katalog koji podržava različite Web 2.0 sadržaje kao što je tagiranje, komentiranje, socijalne mreže i RSS izvore; pristup osobnim stranicama u javnom katalogu; mogućnost izrade popisa literature; podesivo pretraživanje; posudbu i admini-

30 Usp. Sporazum [između Saveznog ministarstva za Europu, integraciju i međunarodne poslove Republike Austrije i Sveučilišta u Zagrebu o osnivanju Austrijske knjižnice Zagreb]. (11.lipnja 2015.) Klasa: 740-06/15-01/34 Ur.br.: 3804-15-1. 
straciju korisnika; modul za nabavu građe; podršku za više knjižnica u sustavu; upravljanje periodičnom građom; modul za izvještaje i druge alate za podršku poslovanju knjižnice“311, sistemska knjižničarka mogla je dobiti podatke o posudbi u razdoblju od 11. lipnja 2015. do 20. travnja 2017. (slika 4). ${ }^{32} \mathrm{U}$ tom razdoblju posuđene su ukupno 603 jedinice građe iz otvorenog pristupa i zatvorenog spremišta - iz otvorenog pristupa 549 knjiga i 4 DVD-a, a 50 knjiga iz zatvorenog spremišta. Kriteriji za smještanje građe u zatvoreno spremište su zbog nedostatka prostora - treći primjerak ili više primjeraka pojedinog naslova u zbirci te knjige u lošem stanju. Kao što smo iz prakse već mogli primijetiti, podaci iz sustava to su i potvrdili. AKZ je svojevrsna nadopuna Germanističkoj zbirci koja je „osnovana 1904. godine kao priručna knjižnica Odsjeka za njemačku filologiju“ ${ }^{33} \mathrm{AKZ}$ posjeduje građu koju Germanistička zbirka nema ili u kojoj oskudijeva, poput primarnih književnih djela austrijske književnosti iz prve i druge polovice 20. stoljeća, s posebnim naglaskom na suvremenoj austrijskoj književnosti, što se može vidjeti iz podataka o 113 posudbi književnih djela iz prve polovice 20. stoljeća i 130 posudbi književnih djela iz druge polovice 20 . stoljeća te 54 posudbe djela o znanosti o književnosti (povijest književnosti, teorija književnosti, biografije i interpretacije austrijskih književnika), 55 posudbi građe o povijesti Austrije i 50 posudbi iz zatvorenog spremišta, među kojima su primarna književna djela iz prve polovice 20. stoljeća.

\subsection{Odnos Austrijske knjižnice Zagreb i osnivača}

Svaka knjižnična zbirka koja je danas dostupna studentima i profesorima u Knjižnici Filozofskog fakulteta u Zagrebu rezultat je dugih godina postojanja, djelovanja i rada brojnih seminarskih knjižnica.

Nastanak i izgradnja neke nove knjižnične zbirke u bilo kojoj fakultetskoj knjižnici obično se odvijaju postupno. Građa se prikuplja polako, prema zahtjevima koje nameće studijski program, često radi otvaranja novog studija, a u dogovoru između knjižničara i profesora koji su nositelji novih kolegija. Svaka nova zbirka obvezno tematski i sadržajno pokriva područje određene studijske grupe ili programa koji se izvode i studiraju na Filozofskom fakultetu u Zagrebu. Kroz dugu povijest knjižničnog djelovanja na Filozofskom fakultetu pratimo povijest razvoja visokoškolskih knjižnica s područja humanističkih i društvenih znanosti i šire.

\footnotetext{
31 Koha Croatian user group. Dostupno na https://saturn.ffzg.hr/koha-cug/index.cgi [citirano: 2017-20-4].

32 Glavica, Marijana. Austrijska knjižnica - posudba. Privatna poruka. (21.4.2017.)

33 Zbirka za germanistiku. [citirano: 2017-20-4]. Dostupno na http://www.ffzg.unizg.hr/german/ cms/index.php?option $=$ com_content\&task=view\&id=12\&Itemid $=29$.
} 
Austrijska knjižnica Zagreb imala je posve drugačiji početak rada u Knjižnici Filozofskog fakulteta u Zagrebu. To je nedjeljiva zbirka u vlasništvu Republike Austrije, a posuđena je Knjižnici FF na neograničeno vrijeme. Kao i 65 drugih austrijskih knjižnica u svijetu, financirana je od Saveznog ministarstva za Europu, integraciju i vanjske poslove Republike Austrije (BMeiA) koja je njezin vlasnik i osnivač. Knjižnica FF postala je matična ustanova AKZ-a, daje mu prostor, smještaj, stručnu obradu, znanstvenog voditelja i knjižničara, a pravila posudbe ista su za AKZ kao i za sve zbirke u Knjižnici FF.

Proces prihvaćanja nove zbirke u okvire svoje fakultetske knjižnice odvijao se između uprave Filozofskog fakulteta i Austrijskog kulturnog foruma. Kako je u standardima za visokoškolske knjižnice u Republici Hrvatskoj propisano, „Fakultetska knjižnica i njoj pridružene odjelne knjižnice odnosno središnja knjižnična služba fakulteta i njoj pridružene odjelne knjižnice, organizirana je kao stručna organizacijska jedinica čije planove, programe i izvještaje odobrava i ocjenjuje znanstveno-nastavno vijeće fakulteta te ih prosljeđuje na usvajanje nadležnom upravnom tijelu i matičnoj sveučilišnoj knjižnici.“ Knjižnični odbor nije imao prostora za postavljanje bilo kakvih upita. Matična služba pri Nacionalnoj i sveučilišnoj knjižnici koja je nadležna za rad Knjižnice nije bila ni obaviještena da Knjižnica Filozofskog fakulteta dobiva kompletnu novu zbirku. ${ }^{34}$

AKZ donosi brojne obveze predmetnoj knjižničarki koja se brine za još dvije zbirke u Knjižnici Filozofskog fakulteta: drugu zbirku po veličini u Knjižnici Filozofskog fakulteta - Germanističku zbirku - te zbirku koja je proizišla iz Germanističke zbirke kao rezultat održavanja izbornog kolegija, a kasnije i zasebnog studija koji djeluje kao katedra, a to je Nederlandistička zbirka. Predmetna knjižničarka obavlja sav posao (nabavu, inventarizaciju, formalnu i sadržajnu obradu) uz pomoć demonstratora, pomagača u knjižnici koji pod mentorstvom knjižničara sudjeluju u stručnoj obradi i zaštiti građe ${ }^{35} \mathrm{AKZ}$ nameće organizaciju brojnih događanja, uređivanje mrežnih i Facebook-stranica, ali i dodatne mogućnosti suradnje s austrijskim kulturnim i znanstvenim institucijama. Knjižnica Filozofskog fakulteta dobila je sasvim novu dimenziju, zadaću i obvezu. Osim odgovornosti prema potrebama svojih prvih korisnika, studenata, profesora i istraživača s područja humanističkih i društvenih znanosti, koje pokrivaju sve studijske grupe na Filozofskom fakultetu, Knjižnica FF sada je obvezna pokrivati i šire zadaće koje traži AKZ.

34 Sukladno odredbama Zakona o knjižnicama (»Narodne novine« broj 105/97, $5 / 98$ i 104/00), čl.31 stavak 3. donesen je Pravilnik o matičnoj djelatnosti knjižnica u Republici Hrvatskoj prema kojem NSK Zagreb sudjeluje u unapređivanju, organiziranju, osiguravanju i podršci kvalitetnom radu visokoškolske knjižnice. [citirano: 2017-11-1]. Dostupno na http://narodne-novine.nn.hr/ clanci/sluzbeni/2001_05_43_715.html.

35 Kulaš, Vanja. Institut demonstratora u Knjižnici Filozofskog fakulteta u Zagrebu. // HKD-Novosti, 63(2014). [citirano: 2017-20-4]. Dostupno na http://www.hkdrustvo.hr/hkdnovosti/clanak/912. 


\section{Zaključak}

Do danas je otvoreno 65 austrijskih knjižnica u 28 država svijeta. Prva austrijska knjižnica otvara se 1986. u Krakovu u Poljskoj, a od 1989. godine Ministarstvo vanjskih poslova Republike Austrije pokreće program za lektore njemačkog jezika na nekadašnjem području Habsburške Monarhije, na sveučilištima, u svrhu širenja jezika te kako bi ponovno ojačali kulturne veze s Austrijom, a knjižnice se isprva osnivaju kao potpora tom programu u gradovima i sveučilišnim centrima u kojima nema austrijskih kulturnih foruma. Austrijski kulturni forumi osnivaju se isključivo u glavnim gradovima. Stoga ne čudi da se najveći broj knjižnica nalazi u Češkoj, Poljskoj, Mađarskoj i Hrvatskoj, i to pri sveučilišnim i fakultetskim, a rjeđe pri narodnim knjižnicama. Sve austrijske knjižnice u svijetu nedjeljive su zbirke u vlasništvu Saveznog ministarstva za Europu, integraciju i vanjske poslove Republike Austrije (BMeiA), koje je ujedno njihov osnivač i koje financira izgradnju zbirki, a infrastrukturu i osoblje osiguravaju matične ustanove u kojima su knjižnice smještene. Knjižnice u matičnim ustanovama imaju status posudbe na neograničeno vrijeme. Odjel za kulturu Saveznog ministarstva (BMeiA), osim što uz potporu lokalnih veleposlanstava i austrijskih kulturnih foruma vodi organizaciju i koordinaciju austrijskih knjižnica te na taj način sudjeluje $u$ organizaciji događanja u knjižnici, vrlo uspješno okuplja sve austrijske knjižnice i njihove djelatnike na svojevrsnoj platformi za umrežavanje Österreich-Bibliotheken im Ausland (http://www.oesterreich-bibliotheken.at/), što je vidljivo i u izvješću ${ }^{36}$ za 2015. godinu. Cjelokupni fond austrijskih knjižnica iznosi 432000 jedinica knjižnične građe. Austrijske knjižnice godišnje imaju oko 388000 korisnika i organiziraju oko tisuću različitih kulturnih i znanstvenih događaja.

U Hrvatskoj tako djeluju četiri austrijske knjižnice. U Osijeku pri Gradskoj i sveučilišnoj knjižnici od 1995. godine djeluje Austrijska čitaonica Osijek, koja je ujedno i središnja knjižnica Nijemaca i Austrijanaca u Republici Hrvatskoj, a po namjeni i sadržaju narodna knjižnica. Godine 2011. otvara se Austrijska knjižnica Rijeka pri Filozofskom Fakultetu Sveučilišta u Rijeci, po namjeni i sadržaju fakultetska knjižnica, potom se 2013. godine pri Sveučilišnoj knjižnici Zadar otvara Austrijska knjižnica ,Dr. Alois Mock“, po namjeni i sadržaju fakultetska knjižnica te se, naposljetku, 2015. godine pri Filozofskom fakultetu Sveučilišta u Zagrebu, povodom šezdesete obljetnice osnutka Austrijske čitaonice, čija knjižnica čini temelj nove knjižnice, otvara Austrijska knjižnica Zagreb, koja je po namjeni i sadržaju fakultetska knjižnica.

Nova zbirka obogatila je Knjižnicu Filozofskog fakulteta, nadopunila je Zbirku za germanistiku, časopisi i novine obogatili su Zbirku periodike, a AV-građa upotpunila je Audio-vizualnu zbirku.

36 Usp. Die Bibliotheken : Bibliotheksverzeichnis. Nav. dj. 
Austrijska knjižnica Zagreb donijela je mnoge obveze predmetnom knjižničaru koji brine za još dvije zbirke u Knjižnici Filozofskog fakulteta. Nametnula je i organizaciju brojnih događanja Austrijske knjižnice Zagreb, uređivanje mrežnih i Facebook-stranica, ali i pružila mogućnost suradnje s austrijskim kulturnim i znanstvenim institucijama.

\section{LITERATURA}

Agramer rječnik njemačkih posuđenica u zagrebačkom govoru / Zrinjka Glovacki-Bernardi, Lara Hölbing Matković, Sanja Petrušić-Goldstein. Zagreb : Novi Liber, 2013.

Die Bibliotheken : Landkarte // Österreich-Bibliotheken im Ausland. [citirano: 201720-1]. Dostupno na http://www.oesterreich-bibliotheken.at/landkarte.pdf

Die Bibliotheken : Bibliotheksverzeichnis // Österreich-Bibliotheken im Ausland. [citirano: 2017-21-1]. Dostupno na http://www.oesterreich-bibliotheken.at/verzeichnis. php

Erl Šafar, Marija. Knjižnica u multikulturalnoj sredini-Austrijska čitaonica Gradske i sveučilišne knjižnice Osijek. // 4. međunarodni stručni skup Knjižnica - središte znanja i zabave : zbornik radova. Karlovac: Gradska knjižnica „Ivan Goran Kovačić", 2008. Str. 95-101.

Glavica, Marijana. Austrijska knjižnica - posudba. Privatna poruka (21.4.2017.)

Karlović, Zvjezdana. Korisnici Austrijske knjižnice. Privatna poruka (19.4.2017.)

Koha Croatian user group. [citirano: 2017-20-4]. Dostupno na https://saturn.ffzg.hr/ koha-cug/index.cgi

Kulaš, Vanja. Institut demonstratora u Knjižnici Filozofskog fakulteta u Zagrebu. // HKD-Novosti, 63(2014). [citirano: 2017-20-4]. Dostupno na http://www.hkdrustvo. $\mathrm{hr} / \mathrm{hkdnovosti} /$ clanak/912

Lacko Vidulić, Svjetlan. Tekst o Austrijskoj knjižnici. Privatna poruka (24. 4. 2017.)

Obad, Vlado. Roda Roda und die deutschsprachige Literatur aus Slawonien. Wien; Köln; Weimar: Böhlau, 1996.

Od utorka do utorka : Austrijski kulturni institut/forum u vlastitim dokumentima : spomen spis u povodu jubileja Austrijskog kulturnog foruma /priredila Truda Stamać. Zagreb : Durieux, 2006.

Pavić Pintarić, Anita. Austrijska knjižnica Zadar. Privatna poruka. (13.4.2017.)

Popis stanovništva kućanstva i stanova 2011. Stanovništvo prema narodnosti po gradovima/općinama. [citirano: 2017-20-4]. Dostupno na http://www.dzs.hr/Hrv/censuses/census2011/results/htm/H01_01_04/h01_01_04_RH.html 
Standardi za visokoškolske knjižnice u Republici Hrvatskoj. // Vjesnik bibliotekara Hrvatske 33, 1-4(1990), 201-209.

Stojić, Aneta. Austrijska knjižnica Rijeka. Privatna poruka. (6.4.2017.)

Pravilnik o matičnoj djelatnosti knjižnica u Republici Hrvatskoj. // Narodne novine 43/2001. [citirano: 2017-11-1]. URL: http://narodne-novine.nn.hr/clanci/sluzbeni/2001_05_43_715.html

Sporazum [između Saveznog ministarstva za Europu, integraciju i međunarodne poslove Republike Austrije i Sveučilišta u Zagrebu o osnivanju Austrijske knjižnice Zagreb]. (11. lipnja 2015.) Klasa: 740-06/15-01/34 Ur.br.: 3804-15-1.

Stanarević, Snježana; Siniša Petković; Darko Lacović. Petnaest godina djelovanja Austrijske čitaonice pri Gradskoj i sveučilišnoj knjižnici Osijek. // 6. međunarodni stručni skup Knjižnica - središte znanja i zabave : zbornik radova. Karlovac: Gradska knjižnica „Ivan Goran Kovačić“, 2008. Str. 30-41.

Todorčev Hlača, Katarina. Strategija razvoja središnjih knjižnica nacionalnih manjina unutar mreže narodnih knjižnica. // Vjesnik bibliotekara Hrvatske 58, 1-2(2015), $45-66$.

Über uns : Geschichte // Österreich-Bibliotheken im Ausland. [citirano: 2017-19-1]. Dostupno na http://www.oesterreich-bibliotheken.at/

Zbirka za germanistiku. [citirano: 2017-12-4]. Dostupno na http://www.ffzg.unizg.hr/ german/cms/index.php?option=com_content\&task=view\&id=12\&Itemid=29 